\title{
HOAX BOMB THREATS AS THE ACTS OF UNLAWFUL INTERFERENCE THAT ENDANGER AVIATION SAFETY AND AIR TRANSPORTATION
}

\author{
I Gusti Ngurah Ardita \\ $\mathrm{PhD}$ of Law Student of Universitas Udayana \& Managing Director of ITDC The Nusa \\ Dua \\ email igustingurahardita@gmail.com/ arditangurah5@gmail.com.
}

Ibrahim R.

Universitas Udayana

email mrprof.ibrahim@gmail.com

Desak Putu Dewi Kasih

Universitas Udayana

email dewiksh@ymail.com

\begin{abstract}
Aviation safety is an important part of the aviation industry around the world. In international and national law in many countries, the unlawful acts that endanger the safety of aviation and air transportation are regulated in a legal instrument. One form of unlawful actions that endangers the safety of aviation and air transportation is the spread of hoax bomb threats. This prohibition is also associated with the efforts of countries to tackle terrorism. In this study, there are several interesting legal issues discussed, namely aspects of aviation safety, hoax bomb threats as a violation of law, criminal jurisdiction in a moving aircraft and legal liability of passengers committing hoax bomb threats. Aviation safety culture is the responsibility of all stakeholders. The hoax bomb threat is a false information that endangers flight safety. The applicable criminal jurisdiction is the law of the country where the aircraft is registered. These provisions apply to both the citizens of the country concerned and foreign nationals.
\end{abstract}

Keywords. Hoax bomb threat, jurisdiction, aviation

\section{Introduction}

Globalization has implications for the ease of movement of people from one area to another through the transportation system. Civil aviation is one of the most needed means of transportation in all corners of the world because it is very effective in terms of travel time. Without flights, people in the world cannot travel to each region or country in an effective time. Aviation as a means of air transportation must be organized and managed in a unified national and international transportation system and able to 
realize the provision of transportation services that are balanced with the level of need and the availability of safe, comfortable, orderly and smooth transportation services. Commercial air transportation is currently progressing very rapidly, this can be seen from the number of airline companies providing cheap, convenient transportation services for the community. ${ }^{1}$

The number of flights is increasing rapidly every year, even though it experienced a significant decline during the Covid-19 pandemic in which international flights were closed. This transportation is considered the safest and most effective, even the technology in the plane is believed to be able to reduce the development of the virus. Even though it is considered effective, civil aviation has a very big risk if it is negligent in ensuring the safety and security of aviation. For this reason, the International Civil Aviation Organization (ICAO) as the Civil Aviation Organization has the authority to regulate the safety and security of international civil aviation based on the 1944 Chicago Convention. ${ }^{2}$

In public international air law, there is the 1944 Chicago Convention that is the constitution of international civil aviation. The convention is used as a reference in making national laws for ICAO member countries for the implementation of international civil aviation. One of the important issues discussed in the Chicago Convention is the issue of criminal jurisdiction in aviation. In fact, since 1902, France as a pioneer in international air law has discussed jurisdictional competence against criminal offenses and crimes that occur in aircraft, as well as actions that need to be taken during the flight. ${ }^{3}$ In 1963, the 1963 Tokyo Convention (Convention on Offences and Certain Other Acts Committed on Board Aircraft) was held. It is a convention that regulates criminal acts and certain acts committed on board aircraft. The actions referred in this convention include acts that are violation of criminal law or not but may interfere the flight security and safety.

Aviation safety is a condition where safety requirements are met in the use of airspace, aircraft, airports, air transportation, flight navigation, as well as the supporting facilities and other public facilities. In both military and civil aviation, aviation safety is carried out by the government. One of the things that endanger flight safety is the crime on board. International Conventional for The Suppression of Terrorist Bombings, 1997 essentially can take actions if necessary to eradicate terrorism and all actions that become its attributes such as hoax bomb threats. Countries in the world regulate various provisions to prevent terrorism, one of which is regulating the act of spreading false information about the existence of bombs that can interfere the flight safety. This international agreement was ratified by Indonesia with the Law of the Republic of Indonesia Number 5 of 2006 concerning Ratification of the International Conventional for The Suppression Of Terrorist Bombings, 1997.

Hoax bomb threat is false information about the presence of bombs either on the plane or at the airport. Hoax bomb threats have occurred in several countries, and it is possible that they were carried out by foreign nationals. Lion Air flight JT-323 experienced a delay of about 45 minutes. This is because there are passengers who convey false news (hoax) about the existence of a bomb. When the passengers entered the cabin (boarding), one of the male passengers with the initials D who had seat number 19A said there was a bomb in his luggage. Responding to the joke about the bomb, the cabin crew coordinated with aviation security officers to ascertain the bomb threat. ${ }^{4}$ The Konrad Adenauer Airport Authority in Cologne, Germany, was forced to cancel a flight to Istanbul after receiving reports of a bomb threat. Around 111 passengers who were originally sitting neatly on the Turkish Airlines airline were evacuated out by security forces who wanted to confirm the truth. The plane, which was originally planned to take off from Cologne to Istanbul, had to be cancelled after Turkish Airlines received a call from an unknown

\footnotetext{
${ }^{1}$ Banjarnahor, A. F., Hasibuan, S. H., Manalu, K. A., Manao, S., \& Sidiq, M. (2020). Pertanggungjawaban Pidana Korporasi Maskapai Penerbangan Sipil Dalam Uu No 1 Tahun 2009 Tentang Penerbangan. Jurnal Ilmiah Simantek, 4(3), 85-94.

2 Triyana, M. B. (2020). Aspek Keselamatan dan Keamanan Penerbangan dalam Hukum Internasional dan Implementasinya di Indonesia.

${ }^{3}$ Manullang, Y. N., Widodo, H., \& Angwarmasse, P. Y. (2019). Aspek Hukum Internasional Terhadap Yurisdiksi Dalam Mengadili Pelaku Pembajakan Pesawat Udara. Krisna Law, 1(3), 109-128.
}

4 Detiknews, "Ada Hoax Bom, Penerbangan Lion Air Banjarmasin-Jakarta Delay 45 Menit" selengkapnya https://news.detik.com/berita/d-4725863/ada-hoax-bom-penerbangan-lion-air-banjarmasin-jakarta-delay-45menit. 
person. The Virgin Airlines flight passengers were evacuated because there was a bomb threat written on a vomit bag. The object was found in the plane's toilet area and was declared a hoax, not a bomb. ${ }^{5}$

Hoax bomb threat is a serious offense under Australian law. The offender made two telephone calls from Newcastle, New South Wales - one to Mumbai International Airport Limited and the other to Singapore Airlines Ground Handling Agency in India. The purpose of the calls was to induce the false belief that an explosive had been left on a Singapore Airlines flight. The flight, at the time, had left Mumbai, India, and was mid-flight en route to Singapore. The hoax bomb threat was treated with due seriousness including scrambling two F16C/D fighter jets to accompany the flight into Changi Airport in Singapore and security personnel subjecting the airplane and all cargo to additional security scanning upon landing. This case was a serious example of the offense provision of 'use carriage service for hoax threat' under s474.16 of the Criminal Code (Cth). Most of the cases perpetrated by the CDPP under this offense provision are perpetrated in the lower courts. The seriousness of this case led the CDPP to prosecuting this charge on indictment in the District Court. ${ }^{6}$

The importance of transportation is reflected in the increasing need for transportation services for the mobility of people and goods within the country, from and to abroad, as well as acting as a driver and driving force for regional growth and development. Recognizing the role of transportation, the operation of flights must be organized into a unified national transportation system in an integrated manner and capable of realizing the provision of transportation services that are balanced with the level of need, safety, security, effectiveness and efficiency. In this study, there are several interesting legal issues discussed. Normatively, it is necessary to study the aspects of aviation safety and hoax bomb threats as an act against the law. Further studies will be conducted regarding criminal jurisdiction in a moving aircraft to find out which law that can be applied if a passenger, including when the passenger is a foreign national, commits a hoax bomb threat.

\section{Aviation Safety and Security Aspects}

Indonesia is an archipelagic country. It is due to the geographical location of Indonesia consisting of thousands of islands, both large and small islands. These developments have had a positive impact on transport users. Indonesia is also located in a strategic position between two oceans, namely the Indian and Pacific oceans, as well as between two continents, namely Asia and Australia. Thus, Indonesia directly border with ten neighbouring countries, namely Australia, Timor Leste, Papua New Guinea, Palau, the Philippines, Malaysia, Vietnam, Thailand, Singapore and India. ${ }^{7}$

The existence of transportation facilities in human life is very influential because it is as a support for the smooth running of human life, it is also useful to connect parts of Indonesia. Therefore, transportation is needed, whether it is transportation between cities or between islands, both for domestic and international relations between countries. The importance of transportation is reflected by the increasing need for transportation services that is as a means of movement of people and goods both from within the country and abroad, transportation also plays a role as a driving force for regional growth and development. ${ }^{8}$ The progress of transportation will have implications for the increasing economic activity and the welfare of the community. Therefore, regulation and supervision of the aviation industry is very important in the transportation sector.

The implementation of the national aviation industry in the recent years is still causing problems. One of them is the frequent occurrence of aircraft accidents causing losses to the passengers as

\footnotetext{
5 Tanti Yulianingsih, "Tak Hanya Lion Air, Hoax Bom juga Pernah Melanda 3 Maskapai Dunia Ini," https://www.liputan6.com/global/read/3543206/tak-hanya-lion-air-hoax-bom-juga-pernah-melanda-3-maskapai-dunia-ini.

6 The Office of the Commonwealth Director of Public Prosecutions, "Hoax bomb threat a serious matter", https://www.cdpp.gov.au/case-reports/hoax-bomb-threat-serious-matter

${ }^{7}$ Bimo, E. A., Prabawa, E., Sembiring, E. K., Ramsi, O., Sjamsoeddin, S., Yusgiantoro, P., \& Midhio, I. W. (2022). The Application of AHP and PESTEL-SWOT Analysis on The Study of Military Amphibious Aircraft Acquisition Decision Making in Indonesia. Technium Social Sciences Journal, 27, 837-853.

8 Agafta, M. P. S., \& Adianto, A. (2017). Tanggung jawab maskapai penerbangan terhadap keterlambatan penerbangan. Mimbar Keadilan, 146-159.
} 
consumers. These accidents can be caused by various factors, starting from human error, problems with aircraft engines (machine / technical) to weather factors. Some experts in the field of aviation have also found the fact that the more sophisticated the technology of flight equipment to reduce or minimize certain specific situations, such as detecting aircraft approaching or automatic landing technology, the greater the possibility of the flight captain will experience errors or omissions. ${ }^{9}$

The United States Congress assigned the FAA to assure the highest degree of safety in flight. The FAA is responsible for providing advice, guidance and oversight in the field of safety to the aviation industry. There are three elements contributing to flight safety. First, the aircraft itself, how it is designed, built, and maintained; Second, the country's aviation system, airports, air traffic lanes, and air traffic controls; Third, airlines flight operations related to aircraft control and operation. ${ }^{10}$ Aviation safety is an obligation and at the same time the right of everyone involved in aviation.

Security systems are designed to protect assets from a threat. The first key point to a successful implementation of a security system is to successfully secure the system itself. According to the Regulation of the Minister of Transportation of the Republic of Indonesia Number 127 of 2015, the National Aviation Security Program is a written document containing regulations, procedures and security measures taken to protect flights from unlawful acts. Security control is the application of a technique or action to prevent the infiltration/carriage of prohibited items that can be used to carry out unlawful acts. ${ }^{11}$ Action against the law is an act that endangers the safety of aviation and air transportation.

An effort to build stakeholders in aviation activities that have a culture of complying with legal rules related to aviation activities, is to create the legal awareness (rechtsbewustzijn) for the stakeholders of these aviation activities. Awareness to comply with the rule of law can certainly be carried out properly if the stakeholders in the flight activity have a high legal culture to comply with all regulations related to efforts to implement aviation safety. ${ }^{12}$ This thing brings up the term called aviation safety culture.

Safety culture is something that is obtained through a combination process of organizational, professional and also national culture. One of the efforts to implement the aviation safety culture is training to introduce the culture to the stakeholders in aviation activities (introduces the culture during training season), where all employees of agencies engaged in aviation activities are given the training; therefore, they have knowledge in implementing the safety culture, so that later they can understand and know well what aviation safety culture is and how to implement it. By providing a good understanding for the stakeholders in these flight activities well, through the education and training process, safety culture can run well. ${ }^{13}$

In ensuring the realization of flight operations that meet safety and security standards, the legal system in Indonesia regulates a number of regulations, namely the establishment of a national aviation safety program, a national aviation security program, and a cultural safety action program that refers to ICAO regulations. The national aviation safety program contains safety regulations, safety objectives, safety reporting systems, safety data analysis and exchange, accident and incident investigations, safety promotions, safety oversight, and law enforcement. Meanwhile, the national aviation security program contains security regulations, security targets, security personnel, division of security responsibilities, protection of airports, aircraft and navigation facilities, control and guarantee of security of people and goods on aircraft, countermeasures against unlawful acts, system adjustments security against the level of security threats, and aviation security supervision.

\footnotetext{
9 Puspandari, Retno. (2017). Tanggung Jawab Perusahaan Jasa Penerbangan terhadap Kecelakaan pada Penumpang Berdasarkan Undang-undang Nomor 1 Tahun 2009 Tentang Penerbangan. Jurnal Privat Law, Vol. 5 (No.1), pp. 95-105.

10 Sundoro, Y. A., \& Hananto, P. W. H. (2020). Sanksi Hukum Penerbangan Balon Udara Ilegal di Kabupaten Wonosobo. Jurnal Pembangunan Hukum Indonesia, 2(2), 246-260.

11 Koloay, J. S. (2018). Kerjasama Sipil-Militer Dalam Pengelolaan Sistem Keamanan Di Bandara Internasional Eltari Kupang. Strategi dan Kampanye Militer, 4(1).

${ }^{12}$ Walewangko, M. (2021). Budaya Keselamatan Penerbangan Berdasarkan Undang-Undang Nomor 1 Tahun 2009 Tentang Penerbangan. Lex Administratum, 9(3), 122-132.

${ }^{13}$ Supriyadi, Y. (2012). Keselamatan penerbangan: teori dan problematika. PT Telaga Ilmu Indonesia, p. 67.
} 
Several important achievements in the field of aviation safety and security include the Federal Aviation Authority (FAA) setting Indonesia's safety in Category 1 (Comply With International Rule). This determination shows that the safety of Indonesian flights has reached FAA standards; therefore, Indonesian airlines can serve flights to/from the United States. The exit of 3 Indonesian airlines, namely Citilink, Lion Air and Batik Air from the EU Operating Ban, that means allowing these airlines to fly to Europe. Another achievement is the release of the ICAO-USAP Audit (International Civil Aviation Organizations-Universal Security Audit Program) stating that Indonesia's aviation security performance reached a value of $93.75 \%$, better than the USAP audit result in 2013 with a score of $82.3 \%{ }^{14}$ The community has an important role in supporting the improvement and culture of aviation safety.

\section{Hoax Bomb Threat as A Violation of Law}

Aviation is part of the national transportation system that has the characteristics of being able to move quickly, using high technology, being capital intensive, reliable management, and requiring optimal safety and security guarantees steady and dynamic national distribution. Aviation is a unified system consisting of the use of airspace, aircraft, airports, air transportation, flight navigation, safety and security, the environment, as well as supporting facilities and other public facilities.

Airplanes as a means of transportation with high technology make every distance no longer an obstacle to be taken. However, it is not directly proportional to the setting. Violations of aviation law are the result from a lack of awareness in complying with applicable laws and regulations. The spread of false information about bombs is one of the most frequent cases of action in which the resolution of the case ends by deliberation or simply giving a warning letter to the perpetrator. This phenomenon is certainly a legal setback, in which the law is considered something that makes it difficult and people choose to take the easy way that does not cause a deterrent effect to the perpetrators. ${ }^{15}$ Hoax bomb threat is basically an unlawful act that endangers the safety of state aviation and transportation. The consequences of this act will certainly extend to flight delays that will harm passengers as consumers in air transportation.

Hoax bomb threat is an issue raised in various international forums because it is often associated with terrorism. International attention to the issue can be seen in the various international conventions that were formed. The 1988 UN Convention against the Illicit Traffic in Narcotic Drugs and Psychotropic Substances was the first international convention that criminalised money laundering and terrorism financing (Bewley-Taylor, 2003; Naheem, 2020). The Financial Action Task Force's (FATF) 40 Recommendations (1990) were aimed at improving national legal systems, enhancing the role of the financial sector and intensifying cooperation in the fight against money laundering. The UN Convention Against Transnational Organized Crime (2003) and the UN Convention Against Corruption (2005) declared that the offence of money laundering should not only apply to the proceeds of illicit drug trafficking but should also cover the proceeds of all serious crimes (Rose, 2020). The UN General Assembly Resolution 60/288 (Sep. 2006) is a unique global instrument that was intended to enhance national, regional and international efforts to counter-terrorism (Rosand, Millar \& Ipe, 2008). ${ }^{16}$

This act is part of the community's pessimistic attitude towards terrorism crimes that occur in the community. The impact of terrorism that has spread to political affairs and even people's social life causes people feel embarrassed and make all things related to terrorism scary. This condition is then used by perpetrators of criminal acts of terrorism as a loophole. The appearance of the bomb joke itself is a condition that supports terrorism. Although many incidents that occurred were not carried out by

\footnotetext{
14 Kementerian Komunikasi dan Informasi, "Budaya Keselamatan Penerbangan", https://jabarprov.go.id/index.php/artikel/detail_artikel/303/2016/12/04/Budaya-Keselamatan-Penerbangan

15 Jeny, S. P. (2020). Pengaturan Tentang Larangan Perbuatan Yang Membahayakan Keselamatan Penerbangan Sipil Berupa Penyebaran Informasi Palsu Oleh Penumpang Di Dalam Pesawat Udara Menurut Hukum Internasional Dan Hukum Nasional Indonesia (Studi Kasus: Frantinus Nirigi Terkait Bomb Jokes Di Dalam Pesawat Lion Air) (Doctoral dissertation, Universitas Andalas).

${ }^{16}$ Masuku, M. M., Mlambo, V. H., \& Ngwenya, B. J. (2021). The Critical Analyses of Propaganda of the Terrorism Deed. Technium Social Sciences Journal, 25, 619-629.
} 
terrorists, the impact was to their advantage, because the fear was the same as the actual bomb threat. It can be seen from the risk of hoax bomb threat in flights ranging from carrying out mass searches, delaying flights, cancelling flights, even having to vacate the airport. ${ }^{17}$

Hoax is basically fake news. According to Husnun N Djuraid, fake news consists of two words, namely news and lies. News is a report of events (facts) or opinions that are actual (current), interesting and important. ${ }^{18}$ Legally, fake news is news in which there is content that is not in accordance with the truth or actual conditions (materialle waarheid). ${ }^{19}$ Merriam Webster Dictionary describes the purpose of hoaxes, namely ": to trick into believing or accepting as genuine something false and often preposterous. ${ }^{20}$ Fake news means news that cannot be believed to be true, thus, this news can mislead the minds of its readers. Lying means not in accordance with what actually happened. In terms of terms, fake news is the end result of news that is manipulated through a news manipulated process. ${ }^{21}$ There are various characteristics of hoaxes, which are as follows:

a. Leads to anxiety, hatred, and hostility.

b. The source of the news is not clear. Hoaxes on social media are usually unverified, unbalanced media reports and tend to corner certain parties.

c. Filled with fanaticism in the name of ideology, the title, and the delivery is provocative, punishes and hides facts and data. ${ }^{22}$

Hoax Bomb Threat is not just an ordinary joke, but is an act that creates legal liability. According to Goebel, in society, the law has functions, namely 1) determining the pattern of relationships between community members by showing which types of behavior are allowed and which are prohibited; 2) Determining the allocation of authority specifying who may apply coercion, who must obey it, who chooses the appropriate and effective sanctions; 3) Resolving disputes; 4) Maintaining the community's ability to adapt to changing living conditions, namely by reformulating the essential relationships between community members. ${ }^{23}$ Law works by regulating a person's actions or relationships between people in society. For the purposes of this regulation, the law describes its work in its various functions, namely the creation of norms, both those that provide designations and those that determine the relationship between people and people; settlement of disputes; and ensure the continuity of people's lives, namely in the event of changes. ${ }^{24}$

In the Indonesian legal system, Hoax Bomb Threat is regulated as an unlawful act as regulated in the Law of the Republic of Indonesia Number 1 of 2009 concerning Aviation. This provision is regulated in Article 344 regarding Countermeasures against the Law which states as follows:

Everyone is prohibited from carrying out acts of unlawful interference that endanger the safety of aviation and air transportation in the form of:

1. illegally controlling an aircraft in flight or on the ground;

2. taking people hostage on an airplane or at an airport;

3. entering into an aircraft, airport restricted security area, or aeronautical facility area illegally;

4. carrying weapons, dangerous goods and equipment, or bombs into an aircraft or airport without a permit; and

\footnotetext{
17 Sumardiana, B. (2019). Analisis Yuridis Larangan Bomb Joke Dalam Penerbangan Guna Menanggulangi Resiko Terorisme. Jambura Law Review, 1(1), 46-67.

${ }^{18}$ Djuraid, H.N. (2009). Panduan Menulis Berita, UMM Press. p. 9.

${ }^{19}$ Adami, C. \& Ardi, F. (2014). Tindak Pidana Pemalsuan. RajaGrafindo Persada, p. 236

${ }^{20}$ Merriam Webster, "Definition of hoax", https://www.merriam-webster.com/dictionary/hoax

${ }^{21}$ Abede, P.S. (2005). Manajemen Berita antara Idealisme dan Realita. Papyrus, p. 73.

${ }^{22}$ Mauludi, S. (2019). Cerdas menghadapi pencemaran nama baik, ujaran kebencian dan hoax. PT Elex Media Komputindo, p. 12 .

${ }^{23}$ Soemitro, R.H. (2014). Permasalahan Hukum Dalam Masyarakat. Alumni, p. 2.

${ }^{24}$ Raharjo, S. (2009). Hukum dan Perubahan Sosial Suatu Tinjauan Teoretis Serta Pengalaman-Pengalaman di Indonesia. Cetakan Ketiga Genta Publishing. p. 111.
} 
5. conveying false information that endangers flight safety.

The use of criminal law as an effort to overcome social problems (criminal acts) is included in the field of law enforcement (especially criminal law enforcement); therefore, it is often said that politics or criminal law policies are part of law enforcement policies. In the Indonesian legal system, sanctions for perpetrators of Hoax Bomb Threat are regulated in Article 437 paragraph (1) of the Law of the Republic of Indonesia Number 1 of 2009 concerning Aviation which states "Everyone who submits false information that endangers flight safety as referred to in Article 344 letter e shall be punished with with a maximum imprisonment of 1 (one) year. The resolution of hoax cases carried out by law enforcement is not a mere logical process, but a requirement with human involvement in it. This means that in law enforcement, it can be seen as a linear logical process. Rather it is something complex. Law enforcement is no longer the result of logical deduction, but rather the result of choices. Thus, the output of law enforcement cannot only be based on logical predictions, but also things that do not follow logic. ${ }^{25}$

\section{Criminal Jurisdiction of Hoax Bomb Threat in Flight}

An independent country has the right to have sovereignty to regulate everything that exists or happens within its territory, especially the airspace above its territory. Therefore, the state has the authority to establish laws and make decisions on all events involving its airspace. This authority is known as state jurisdiction in international law. ${ }^{26}$ Within the scope of a State's sovereign rights, especially in its national airspace, the complete and exclusive nature concerned have a different meaning from the nature within the scope of state sovereignty in the sea area. This means that with such a nature, in the national airspace, it does not know and does not recognize the term "innocent passage" which is generally available to foreign parties as contained in the territorial sea of a country. ${ }^{27}$

As part of the sovereignty of a country, airspace has a strategic function as a very valuable national asset, including in the interests of defense and security. It is known that national air space is one of the natural resources found in the air, and at the same time it is a national area as a container or space/media, where the Unitary State of the Republic of Indonesia does its sovereignty, sovereign rights and jurisdiction. ${ }^{28}$ Sovereignty is not only limited to the sovereignty possessed by other countries, but it is also limited to the necessity of a State to subject itself legally to international law. Therefore, in this case, sovereign rights are no longer seen as comprehensive and completely intact. This is what is said that the sovereignty possessed by a country does not always have an absolute nature but instead has a relative nature to give respect to the sovereign rights and the unity of the territory of another country within certain limits decided in international law and to be careful not to take actions that violate and cause harm to other countries. ${ }^{29}$

One aspect that needs to be considered in the utilization of airspace and the resources in it is the issue of jurisdiction. The principles in jurisdiction are the principle of territorial, national, passive personality, protection or security, universality, and crime according to applicable legal criteria. In relation to state jurisdiction in airspace, it is closely related to law enforcement in the airspace. With the existence of jurisdiction, the country concerned has the authority and responsibility in the air to carry out law enforcement in airspace. ${ }^{30}$ The study of jurisdiction in an aviation can be seen in various international conventions in the field of aviation.

\footnotetext{
${ }^{25}$ Irmansyah, R.A. (2013). Hukum Hak Asasi dan Demokrasi. Graha Ilmu, p. 83-84.

${ }^{26}$ Santoso, M.S. (2012). Perspektif Imigrasi Dalam Migrasi Manusia. Pustaka Reka Cipta, p. 39.

${ }^{27}$ Clorinda, J. I. U., Santoso, M. I., \& Widodo, H. (2019). "Pelanggaran Hak Lintas Navigasi Oleh Pesawat Asing Di Ruang Udara Teritorial Indonesia". Krisna Law, 1 (3), 77-86

${ }^{28}$ Yunitasari, D. (2020). Penegakan Pelanggaran Kedaulatan Oleh Pesawat Sipil Asing Di Wilayah Yurisdiksi Nasional. Jurnal Media Komunikasi Pendidikan Pancasila dan Kewarganegaraan, 2(1), 35-56.

${ }^{29}$ Hadiwijoyo, S. S. (2011). Perbatasan Negara Dalam Dimensi Hukum Internasional, Graha Ilmu, p. 8.

${ }^{30}$ Darwis, N. (2018). Politik Hukum Memanfaatkan Wilayah Udara Untuk Kepentingan Penerbangan Di Wilayah Kedaulatan NKRI. Jurnal Ilmiah Hukum Dirgantara, 6(1).
} 
Article 1 of the 1919 Paris Convention stipulates that each State respects all matters concerning the ownership of the other State's full and exclusive absolute sovereign rights over the airspace that is directly above its territory. Then in its development, the Chicago Convention was signed by 52 countries on December 7, 1944. It was the adoption of this convention that gave birth to an international organization in the field of aviation, namely ICAO. In this Convention, there are 96 articles divided into 4 parts. The first part discusses air navigation. The second part of the convention discusses the International Organization of Civil Aviation which includes organizational descriptions, organizational meetings, organizational boards, air navigation commissions, organizational personnel, finance, and other international agreements related to aviation. The third section discusses International Air Transport which includes reports and information, airports and other navigation facilities, joint operations and joint services. The last section deals with the final provisions of this convention.

The 1944 Chicago Convention also carries the same basic principles as contained in the 1919 Paris Convention and at the same time strengthens it, namely that basically the sovereign rights of each country are complete and exclusive over the airspace of their sovereign territory. The elaboration of the following article gives the idea that the form of concretization of the existence of complete and exclusive sovereignty over the airspace above its territorial area is: a) Each State has the right to operate and control its national air space as a whole and full; and b) No activity or effort may be carried out at all in the national air space if it does not obtain prior permission or as has been stipulated and written in bilateral or multilateral air agreements carried out between one country and another. ${ }^{31}$

When the session was held in Munich in 1959, the forum participants also mentioned to discuss the jurisdiction of the country registering the aircraft, the jurisdiction of the landing country, and the territorial jurisdiction. Forum participants suggested that jurisdiction over criminal acts of infringement or crimes on board the aircraft is the country of registration of the aircraft. The concept is actually the same as the law of the sea recognized by international law. ${ }^{32}$

Another convention is Convention on Offences and Certain Other Acts Committee on Board Aircraft, 1963 in Tokyo, Japan. The objectives of this convention are as follows: 1) To stipulate the applicable criminal law if a crime occurs over territory that does not belong to a particular country, such as the high seas, or in cases where the crime occurred cannot be determined legally precisely due to the very fast movement of the aircraft; 2) To assert the rights and obligations of the aircraft commander, in connection with the occurrence of criminal acts and other acts on the aircraft that endanger the safety of the aircraft; and 3) To assert the rights and obligations of the competent authorities at the place where the aircraft lands after the occurrence of actions that endanger the aircraft. ${ }^{33}$

Article 3 paragraph (1) of the 1963 Tokyo Convention states "The State of registration of the aircraft is competent to exercise jurisdiction over offenses and acts committed on board aircraft". Article 4 of the 1963 Tokyo Convention states "A Contracting state which is not the state of registration may not interfere with an aircraft in flight in order to exercise its criminal jurisdiction over an offense committed on board except in the following cases: (a) The offense has effect on the territory of such state; (b) The offense has been committed by or against national or permanent residents of such state; (c) The offense is against the security of such state; (d) The offense consists of a breach of any rules regulations relating to the flight or maneuver of aircraft in force in such state; (e) The exercise of jurisdiction is necessary to ensure the observance of any obligation of such State under a multilateral international agreement." Article 4 of the 1963 Tokyo Convention also regulates the jurisdiction of the aircraft registering country. If the country is not an aircraft registering country, then that country cannot exercise jurisdiction over criminal offenses or crimes on board the aircraft. This rule can be excluded if the offense or crime affects its territory or the crime interferes with national security or also certain steps are very necessary to

\footnotetext{
31 Nisa, C. U., \& Disemadi, H. S. (2020). Yurisdiksi Kriminal Terhadap Black Flight Di Ruang Udara Wilayah Indonesia. SASI, 26(3), 365-379.

32 Martono. (1995). Hukum Udara, Angkatan Udara, dan Hukum Angkasa, Hukum Laut Internasional. Mandar Maju, p. 47.

${ }^{33}$ Wiradipradja, E.S. (2014). Pengantar Hukum Udara dan Ruang Angkasa. Alumni, p. 256.
} 
implement the provisions of applicable international law. ${ }^{34}$ Thus, criminal jurisdiction over legal acts committed on board the aircraft is the law of the country of registration.

Jurisdiction issues in aviation are adopted in various laws and regulations. Article 4 of the Law of the Republic of Indonesia Number 1 of 2009 concerning Aviation determines that this Law applies to: a. all activities of using airspace, flight navigation, aircraft, airports, air bases, air transportation, aviation safety and security, as well as supporting facilities and other related public facilities, including environmental preservation in the territory of the Unitary State of the Republic of Indonesia; b. all foreign aircraft conducting activities from and/or to the territory of the Unitary State of the Republic of Indonesia; and c. all Indonesian aircraft that are outside the territory of the Unitary State of the Republic of Indonesia. Articles 5 and 6 further stipulate that the Unitary State of the Republic of Indonesia has full and exclusive sovereignty over the airspace of the Republic of Indonesia. In the context of implementing state sovereignty over the airspace of the Unitary State of the Republic of Indonesia, the Government shall exercise the authority and responsibility for regulating air space for the benefit of aviation, the national economy, state defense and security, social culture, and the air environment.

\section{The Passenger Criminal Liability}

The study of criminal law in addition to discussing criminal acts, also discusses criminal liability. Andi Hamzah argues that responsibility is the obligation to bear everything, if anything happens it can be prosecuted, blamed, and brought to justice. In the legal dictionary, responsibility is a must for someone to carry out what has been required of him. ${ }^{35}$ In discussing criminal responsibility, it cannot be separated from one or two aspects that must be viewed with philosophical views. One of them is justice, so the discussion about criminal responsibility will provide a clearer contour. Criminal responsibility as a matter of criminal law is intertwined with justice as a matter of philosophy ${ }^{36}$ Abdussalam formulates that criminal liability or guilt in a broad sense has three areas, namely: the ability to take responsibility for the person who commits the act; the inner relationship (psychic attitude) of the person who commits the act with his deed (intentional actions, or actions that are alpha, negligent, inadvertent) and there is no reason to erase criminal liability for the perpetrator. ${ }^{37}$

Criminal responsibility will be faced with two genres, namely monistic and dualistic schools. The monistic view states that an act that is punishable by law is an act committed by someone who is guilty, contrary to the law, and that person is considered responsible for his actions. The elements of a criminal act (strafbaar feit) consist of an objective element, namely a common act, and a subjective element, namely an element of maker. Strafbaar feit is a requirement in imposing a crime, so it is considered that if there is a strafbaar feit, then the perpetrator can definitely be punished. ${ }^{38}$ According to Bassiouni, the goals to be achieved by criminals are generally manifested in social interests that contain certain values that need to be protected. According to Bassiouni, these social interests are: maintenance of social order; protection of citizens from crimes, losses or unjustifiable dangers committed by others; resocialization for the violators of the law; maintain or defend the integrity of certain basic views regarding social justice, human dignity and individual justice. ${ }^{39}$

Hoax Bomb Threat is a threat to the public's interests of security. The Decree of the Minister of Transportation of the Republic of Indonesia Number 54 of 2014 explains that security is a combination of human resources, facilities and materials as well as procedures to protect flights from unlawful

\footnotetext{
${ }^{34}$ Manullang, Y. N., Widodo, H., \& Angwarmasse, P. Y. (2019). Aspek Hukum Internasional Terhadap Yurisdiksi Dalam Mengadili Pelaku Pembajakan Pesawat Udara. Krisna Law, 1(3), 109-128.

${ }^{35}$ Hamzah, A. (2005). Kamus Hukum, Ghalia Indonesia, p.. 597.

${ }^{36}$ Saleh, R. (1982). Pikiran-pikiran Tentang Pertanggungjawaban Pidana, Ghalia Indonesia, p. 10

${ }^{37}$ Abdussalam. (2007). Sistem Peradilan Pidana, Restu Agung, p. 58

${ }^{38}$ Muladi dan Dwidja Priyatno. (2010). Pertanggungjawaban Pidana Korporasi, Kencana Prenada Media Group, p. 61

39 Arief, B.N. (2008). Bunga Rampai Kebijakan Hukum Pidana Perkembangan Penyusunan Konsep KUHP Baru, Kencana Prenada Media Group, p 33.
} 
interference. Meanwhile, security control is an effort to prevent the infiltration of weapons, explosives or other materials that may be used to carry out unlawful interference. From the explanation above, it can be concluded that the airport security system is a combined effort of human resources, facilities and materials as well as procedures in a series of elements that work together to prevent the infiltration of weapons, explosives, or other materials at the airport that may be used to take actions against the law, so as to achieve a goal, namely to protect civil aviation from unlawful acts (external causal factor). ${ }^{40}$

Airplane passengers have an interest and right to safety; therefore, the act of spreading Hoax Bomb Threat must result in criminal liability. In view of the provisions regarding criminal jurisdiction as what is expressly regulated in Article 3 paragraph (1) of the 1963 Tokyo Convention, the applicable law is the law in the country of registration of the aircraft. The law of the country of registration of this aircraft has the competence to exercise its jurisdiction over crimes and other acts committed on board the aircraft, including for foreign nationals. For example, a passenger who is a French citizen spreads Hoax Bomb Threat on a plane traveling from Indonesia to Turkey. The aircraft is registered in Indonesia; therefore, the law applied to the French citizen is Indonesian law.

\section{Conclusion}

Hoax Bomb Threat is an act against the law as regulated in international and national law in various countries. In the Indonesian legal system, perpetrators of Hoax Bomb Threat are threatened with a maximum imprisonment of one year. This provision does not only apply to Indonesian citizens, but also to foreign nationals as long as the aircraft is registered in Indonesia. The implementation of a regulation must be accompanied by strong supervision so that there is no disintegration or disorientation in society. The principles of good and correct supervision are goal-oriented supervision; supervision must be subjective, honest and put the public interest above personal interests; supervision must be oriented to the truth according to applicable regulations (wetmatigheid), oriented to the truth of the established procedures (rechmatigheid), and oriented to the goals and benefits of implementation (doelmatigheid); supervision must ensure the efficiency and effectiveness of the work; supervision must be based on objective, accurate, and appropriate standards; supervision must be continuous; the results of the supervision must be able to provide feedback on improvements and refinements and future policies.

\section{References}

[1] Abdussalam. (2007). Sistem Peradilan Pidana, Restu Agung.

[2] Abede, P.S. (2005). Manajemen Berita antara Idealisme dan Realita. Papyrus.

[3] Adami, C. \& Ardi, F. (2014). Tindak Pidana Pemalsuan. RajaGrafindo Persada.

[4] Agafta, M. P. S., \& Adianto, A. (2017). Tanggung jawab maskapai penerbangan terhadap keterlambatan penerbangan. Mimbar Keadilan, 146-159

[5] Arief, B.N. (2008). Bunga Rampai Kebijakan Hukum Pidana Perkembangan Penyusunan Konsep KUHP Baru, Kencana Prenada Media Group.

[6] Bimo, E. A., Prabawa, E., Sembiring, E. K., Ramsi, O., Sjamsoeddin, S., Yusgiantoro, P., \& Midhio, I. W. (2022). The Application of AHP and PESTEL-SWOT Analysis on The Study of Military Amphibious Aircraft Acquisition Decision Making in Indonesia. Technium Social Sciences Journal, 27, 837-853.

[7] Banjarnahor, A. F., Hasibuan, S. H., Manalu, K. A., Manao, S., \& Sidiq, M. (2020). Pertanggungjawaban Pidana Korporasi Maskapai Penerbangan Sipil Dalam Uu No 1 Tahun 2009 Tentang Penerbangan. Jurnal Ilmiah Simantek, 4(3), 85-94.

\footnotetext{
${ }^{40}$ Bate'e, M. M. (2021). Analisis Sistem informasi Manajemen dalam Penanganan Gangguan Keamanan Bandara. Jesya (Jurnal Ekonomi dan Ekonomi Syariah), 4(2), 1034-1044.
} 
[8] Bate'e, M. M. (2021). Analisis Sistem informasi Manajemen dalam Penanganan Gangguan Keamanan Bandara. Jesya (Jurnal Ekonomi dan Ekonomi Syariah), 4(2), 1034-1044.

[9] Clorinda, J. I. U., Santoso, M. I., \& Widodo, H. (2019). "Pelanggaran Hak Lintas Navigasi Oleh Pesawat Asing Di Ruang Udara Teritorial Indonesia”. Krisna Law, 1 (3).

[10] Darwis, N. (2018). Politik Hukum Memanfaatkan Wilayah Udara Untuk Kepentingan Penerbangan Di Wilayah Kedaulatan NKRI. Jurnal Ilmiah Hukum Dirgantara, 6(1).

[11] Detiknews, "Ada Hoax Bom, Penerbangan Lion Air Banjarmasin-Jakarta Delay 45 Menit" https://news.detik.com/berita/d-4725863/ada-hoax-bom-penerbangan-lion-airbanjarmasin-jakarta-delay-45-menit.

[12] Djuraid, H.N. (2009). Panduan Menulis Berita, UMM Press.

[13] Hadiwijoyo, S. S. (2011). Perbatasan Negara Dalam Dimensi Hukum Internasional, Graha Ilmu.

[14] Hamzah, A. (2005). Kamus Hukum, Ghalia Indonesia.

[15] Irmansyah, R.A. (2013). Hukum Hak Asasi dan Demokrasi. Graha Ilmu.

[16] Jeny, S. P. (2020). Pengaturan Tentang Larangan Perbuatan Yang Membahayakan Keselamatan Penerbangan Sipil Berupa Penyebaran Informasi Palsu Oleh Penumpang Di Dalam Pesawat Udara Menurut Hukum Internasional Dan Hukum Nasional Indonesia (Studi Kasus: Frantinus Nirigi Terkait Bomb Jokes Di Dalam Pesawat Lion Air) (Doctoral dissertation, Universitas Andalas).

[17] Jeny, S. P. (2020). Pengaturan Tentang Larangan Perbuatan Yang Membahayakan Keselamatan Penerbangan Sipil Berupa Penyebaran Informasi Palsu Oleh Penumpang Di Dalam Pesawat Udara Menurut Hukum Internasional Dan Hukum Nasional Indonesia (Studi Kasus: Frantinus Nirigi Terkait Bomb Jokes Di Dalam Pesawat Lion Air) (Doctoral dissertation, Universitas Andalas).

[18] Kementerian Komunikasi dan Informasi, "Budaya Keselamatan Penerbangan", https://jabarprov.go.id/index.php/artikel/detail_artikel/303/2016/12/04/Budaya-

Keselamatan-Penerbangan

[19] Koloay, J. S. (2018). Kerjasama Sipil-Militer Dalam Pengelolaan Sistem Keamanan Di Bandara Internasional Eltari Kupang. Strategi dan Kampanye Militer, 4(1).

[20] Manullang, Y. N., Widodo, H., \& Angwarmasse, P. Y. (2019). Aspek Hukum Internasional Terhadap Yurisdiksi Dalam Mengadili Pelaku Pembajakan Pesawat Udara. Krisna Law, 1(3), 109-128.

[21] Manullang, Y. N., Widodo, H., \& Angwarmasse, P. Y. (2019). Aspek Hukum Internasional Terhadap Yurisdiksi Dalam Mengadili Pelaku Pembajakan Pesawat Udara. Krisna Law, 1(3), 109-128.

[22] Martono. (1995). Hukum Udara, Angkatan Udara, dan Hukum Angkasa, Hukum Laut Internasional. Mandar Maju.

[23] Mauludi, S. (2019). Cerdas menghadapi pencemaran nama baik, ujaran kebencian dan hoax. PT Elex Media Komputindo.

[24] Masuku, M. M., Mlambo, V. H., \& Ngwenya, B. J. (2021). The Critical Analyses of Propaganda of the Terrorism Deed. Technium Social Sciences Journal, 25, 619-629.

[25] Merriam Webster, "Definition of hoax", https://www.merriamwebster.com/dictionary/hoax

[26] Muladi dan Dwidja Priyatno. (2010). Pertanggungjawaban Pidana Korporasi, Kencana Prenada Media Group.

[27] Nisa, C. U., \& Disemadi, H. S. (2020). Yurisdiksi Kriminal Terhadap Black Flight Di Ruang Udara Wilayah Indonesia. SASI, 26(3).. 
[28] Puspandari, Retno. (2017). Tanggung Jawab Perusahaan Jasa Penerbangan terhadap Kecelakaan pada Penumpang Berdasarkan Undang-undang Nomor 1 Tahun 2009 Tentang Penerbangan. Jurnal Privat Law, Vol. 5 (No.1), pp. 95-105.

[29] Raharjo, S. (2009). Hukum dan Perubahan Sosial Suatu Tinjauan Teoretis Serta Pengalaman-Pengalaman di Indonesia. Cetakan Ketiga Genta Publishing.

[30] Saleh, R. (1982). Pikiran-pikiran Tentang Pertanggungjawaban Pidana, Ghalia Indonesia.

[31] Santoso, M.S. (2012). Perspektif Imigrasi Dalam Migrasi Manusia. Pustaka Reka Cipta.

[32] Soemitro, R.H. (2014). Permasalahan Hukum Dalam Masyarakat. Alumni.

[33] Sumardiana, B. (2019). Analisis Yuridis Larangan Bomb Joke Dalam Penerbangan Guna Menanggulangi Resiko Terorisme. Jambura Law Review, 1(1), 46-67.

[34] Sundoro, Y. A., \& Hananto, P. W. H. (2020). Sanksi Hukum Penerbangan Balon Udara Ilegal di Kabupaten Wonosobo. Jurnal Pembangunan Hukum Indonesia, 2(2), 246-260.

[35] Supriyadi, Y. (2012). Keselamatan penerbangan: teori dan problematika. PT Telaga Ilmu Indonesia, p. 67.

[36] The Office of the Commonwealth Director of Public Prosecutions, "Hoax bomb threat a serious matter", https://www.cdpp.gov.au/case-reports/hoax-bomb-threat-serious-matter

[37] Triyana, M. B. (2020). Aspek Keselamatan dan Keamanan Penerbangan dalam Hukum Internasional dan Implementasinya di Indonesia.

[38] Walewangko, M. (2021). Budaya Keselamatan Penerbangan Berdasarkan UndangUndang Nomor 1 Tahun 2009 Tentang Penerbangan. Lex Administratum, 9(3).

[39] Wiradipradja, E.S. (2014). Pengantar Hukum Udara dan Ruang Angkasa. Alumni.

[40] Yulianingsih, "Tak Hanya Lion Air, Hoax Bom juga Pernah Melanda 3 Maskapai Dunia Ini," https://www.liputan6.com/global/read/3543206/tak-hanya-lion-air-hoax-bom-jugapernah-melanda-3-maskapai-dunia-ini.

[41] Yunitasari, D. (2020). Penegakan Pelanggaran Kedaulatan Oleh Pesawat Sipil Asing Di Wilayah Yurisdiksi Nasional. Jurnal Media Komunikasi Pendidikan Pancasila dan Kewarganegaraan, 2(1). 